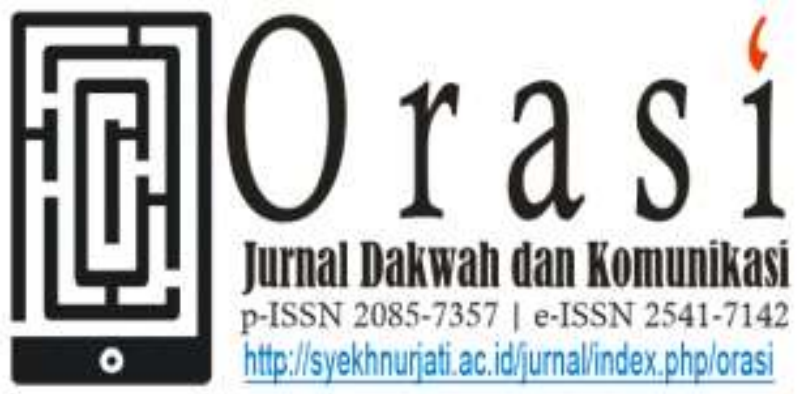

Volume 12 No. 1 Juli 2021

\title{
MODERASI AGAMA NAHDLATUL 'ULAMA DI ERA GLOBAL
}

\section{NAHDLATUL 'ULAMA'S RELIGIOUS MODERATION IN THE GLOBAL ERA}

\author{
M. Alfazri \\ Universitas Islam Negeri Sunan Kalijaga Yogyakarta \\ email: alfazrimohammed@gmail.com
}

\begin{abstract}
Abstrak
Kekaburan dalam meresapi nilai-nilai keagamaan dirasakan menyeluruh oleh semua lapisan masyarakat muslim maupun non-muslim. Masyarakat Muslim seakan menjadi penyumbang kegelisahan dan kesedihan yang tersimpan dibalik remuknya dunia peradaban manusia, meskipun dibangun dengan megahnya. Namun, di dalamnya justru menyimpan kompleksitas masalah umat manusia, di mulai dari keagamaan, ekonomi, politik, pendidikan, sosial hingga humanisme atau kemanusiaan. Disini perlu ada ramuan penyembuh bagi umat Muslim untuk menetralisir fenomena-fenomena tersebut, khususnya dalam segi keagamaan. NU (Nahdlatul 'Ulama) mempunyai peran yang strategis dan vital dalam hal ini, yang dinamakan dengan istilah moderasi agama. Penelitian ini merupakan penelitian kepustakaan (library research). Menggunakan pendekatan perspektif historis, yakni suatu metode kajian dan sumber lain yang memuat informasi tentang masa lalu dan dilakukan secara sistematis. Dengan tujuan memahami masa lalu, dan berusaha memahami masa kini atas dasar peristiwa atau perkembangan di masa lampau.
\end{abstract}

Kata Kunci: Moderasi, Nahdlatul ‘Ulama, Era Global.

\section{ABSTRACT}

The obscurity in perceiving religious values is felt thoroughly by all levels of Muslim and non-Muslim society. The Muslim community seems to be a contributor to the anxiety and sadness that is stored behind the crumbling world of human civilization, even though it is built with grandeur. However, it contains the 
complexities of human problems, ranging from religious, economic, political, educational, social to humanity matters. Hence, a healing for Muslims to neutralize these phenomena is needed, especially in terms of religion. NU (Nahdlatul 'Ulama) has a strategic and vital role in this, which is called religious moderation. This research is a library research, using a historical perspective approach, which examines literatures and other sources that contain information about the past and is carried out systematically, with the aim of understanding the past and trying to embrace the present on the basis of events or developments in the past.

\section{Keywords: Religious Moderation, Nahdlatul 'Ulama, Global Era}

\section{Pendahuluan}

Arogansi dalam memahami agama muncul ketika seseorang atau kelompok mencerna suatu masalah yang muncul di permukaan, enggan menelitinya dari sudut pandang yang lebih dalam. Bahwa sebenarnya semuanya adalah proses menjalani takdir kehambaan. Jika hal ini tidak bisa dipahami oleh hati manusia, maka jiwa akan menjadi gersang. Manusia melesat keluar dari orbit roh mereka. Dia mencoba membangun kerajaannya sendiri, atau planetnya sendiri, dalam kehidupan ini. Manusia kemudian terlepas dari kodratnya. Kemudian menjadi kaku dalam memandang setiap masalah yang ada dalam masyarakat majemuk. Muncullah Klaim bahwa tindakan atau perbuatannya benar, dan apapun yang berbeda salah. Di sini manusia telah mengambil hak prerogatif Tuhan dengan cap benar atau salah yang seharusnya menjadi wilayah kekuasaan keTuhanan yang akan dibuat untuk dirinya sendiri. Di sini kita menemukan dua klaim yang dibuat oleh manusia pertama, amal yang dia lakukan digunakan sebagai legitimasi atau paspor untuk mem-booking surga. Kedua, manusia sendiri adalah pemilik surga, bukan Allah Swt. ${ }^{1}$

Di negeri ini persoalan kemanusiaan semakin bertumpuk dan seakan tidak mampu dibendung. Masalah yang secara langsung berhubungan dengan kehidupan keagamaan, ada pula masalah yang menjadikan agama sebagai trigger sehingga orang saling tidak percaya bahkan bunuh-membunuh. Konflik sosial yang masih baru dirasakan khususnya kesalahpahaman antarkelompok, salah paham dalam hal agama menjadi bagian tak terpisahkan dari kehidupan umat beragama.

Penyakit-penyakit moral seperti korupsi, ketidaktaatan warga negara atas pemerintah karena tiada memberikan teladan, kemalasan anak-anak sekolah untuk belajar, kerusakan sistem di sekolah-sekolah yang menyebabkan pendidikan tidak berjalan dengan baik, budaya pungli, tergesa-gesa dalam beberapa urusan, dan kemalasankemalasan lain yang menyelimuti kehidupan umat beragama merupakan bagian tak terpisahkan yang harus direspons agama-

${ }^{1}$ Ali Ridho, Memahamai Makna Jihad Dalam Serial Film Kartun Cisform: Jihad FiSabilillah (Analisis Wacana Teun A. Van Dijk), (Curup: IAIN Curup, Jurnal Dakwah dan Komunikasi, Vol 4, No. 1, 2019), h. 6 
agama jika agama tidak ingin kehilangan peran vitalnya di tengah gejolak kehidupan umat.

Namun, tentu saja tidak sederhana memberikan beban berat penyakit-penyakit sosial yang terus bertumpuk pada agama. Tetapi, sikap membiarkan penyakit-penyakit sosial tersebut terus menggelinding di tengah masyarakat juga sama artinya dengan meninggalkan tanggung jawab agama pada permasalahan yang dihadapi oleh umat. Persoalannya, kekuasaan acap kali tidak peka dengan persoalan kemanusiaan yang terus bertumpuk, sementara agama juga dikonstruksikan sebagaimana rezim kekuasaan berjalan. Ini adalah problem internal agama yang berhadapan dengan masalah kemanusiaan yang menumpuk.

Sebagai gambaran jelasnya, penyakit sosial korupsi. Korupsi di negeri penduduk mayoritas beragama berada dalam posisi yang mengerikan. Indonesia selalu menjadi juara utama di Asia. ${ }^{2}$ Hal ini menandakan bahwa korupsi memang menjadi masalah serius dalam masyarakat beragama. Korupsi di negeri religius ini dilakukan dari tingkat hulu hingga hilir. Dari tingkat desa hingga pemerintahan pusat. Dari DPR daerah hingga pemerintahan. Bahkan, korupsi juga dilakukan dari rumah

\footnotetext{
${ }^{2}$ Transparency International Indonesia (The Global Coalition Against Corruption) pernah melakukan survey pada tahun 2017 Mengenai Indeks Persepsi Korupsi Indonesia Tahun 2017. Survey antara pelaku usaha di 12 kota di Indonesia pada akhirnya mendapatkan kesimpulan, bahwa tingkat korupsi pada level kota mempunnyai rerata 60.8. Dalam skala 0-100, skor IPK menandakan di atas rata-rata. Jika dibandingkan dengan IPK 2015, di mana rerata saat itu adalah 54,6, maka bisa dikatakan terjadi peningkatan skor yang artinya terjadi perbaikan dalam hal interaksi pelaku usaha dengan pemerintah.
}

ibadah hingga tempat tidur, dari orang awam agama hingga bergelar keagamaan. ${ }^{3}$

Islam merupakan agama yang

dibawa Nabi Muhammad Saw., Islam dipersepsikan sebagai kesakralan ajaran yang moderat di dalamnya, dikenal dengan istilah Moderasi Agama. Dalam struktur ajarannya, Islam menggabungkan dua ekstremitas yang berlawanan. Misalnya, ajaran Islam tidak hanya memuat masalah esoterik ketuhanan, tetapi juga hal-hal lain yang menyangkut kemanusiaan dengan implikasinya dalam kehidupan sehari-hari. Serta mewujudkan nilai-nilai luhur agama dan budaya, kehidupan pribadi, keluarga, masyarakat, bangsa dan negara melalui pendidikan formal, informal dan nonformal. Demikian agar pada tataran praktis tidak terjadi bentrok, ketidakadilan, kesewenang-wenangan, ketidaknyamanan, dan sebagainya.

Masyarakat Indonesia yang penuh dengan kemajemukan sosial-budaya sebagaimana disebutkan diatas, menjadi rentan untuk goyah dengan adanya percikan bara api yang menyulut di tengah-tengah realitas perbedaan yang ada. Diantara contoh yang hangat adalah perbedaan dalam menentukan pilihan dalam Pilpres 17 April tahun 2019

${ }^{3}$ Sementara itu, Transparency International merilis riset Indeks Persepsi Korupsi (IPK) pada Tahun 2018 menemukan bahwa IPK Indonesia naik satu point ke 38 dari sakala 0-100. Dengan nilai tersebut Indonesia berada di peringkat 89 dari 180 negara. Setelah mengalami stagnasi pada tahun 2017, IPK Indonesia berhasil mencatat perbaikan pada tahun lalu. Persepsi korupsi Indonesia sejak 2000 mengalami tren kenaikan. Sementara pemerintahan Joko Widodo-Jusuf Kalla IPK Indonesia naik 4 poin. (lihat: databoks.katadata.com, 29 Januari 2019) 
yang lalu. Dampak negatif nyata yang ditimbulkan ialah terjadinya dinding pemisah persaudaraan dalam lintas keagamaan dan kemanusiaan, dengan disertai saling curiga, kebencian yang digmatis hingga permusuhan yang menjurus kepada fisik. Belum lagi kegaduhan dunia maya yang dihiasi dengan hastag saling menjatuhkan layaknya lawan dalam sebuah pertandingan tinju. Kondisi seperti ini apabila dibiarkan secara berlarutlarut tanpa adanya upaya dari stake holder (pemerintah, organisasi agama dan akademisi) untuk meredam gejolak yang ada, maka Indonesia akan berada dalam situasi genting kehancuran.

Agama harus dihadapkan secara langsung dengan masalah manusiawi yang sebenarnya mengelilinginya, seperti disebutkan di atas. Sebab, hanya disitulah peran vital profetik agama-agama akan bermakna, bukan pada khotbah-khotbah yang tidak mampu bersentuhan dengan realitas kemanusiaan. Misi profetik agama harus diarahkan pada pemberantasan sosial kemanusiaan tanpa pandang agama, suku, jenis kelamin ataupun kelompok etnis mana pun. Pertikaian antar umat agama memang tidak murni karena masalah ketidakpercayaan, tetapi banyak faktor penyebab di dalamnya.

Oleh sebab itu, diperlukan kearifankearifan dalam beragama sehingga misi profetik agama akan terus bergerak menuju perubahan sosial kemasyarakatan. Kearifan misi profetik agama harus terus digali dan ditransformasikan oleh para elite agama serta umat secara keseluruhan. Agama tidak boleh berhenti pada tataran konseptual. Agama harus bergerak pada tataran realitas, sebab agama harus mampu bersentuhan dan menyapa secara langsung pada realitas kehidupan umatnya. Agama tidak boleh berhenti pada cara pandang yang memperkuat tumbuhnya sentimentsentimen kelompok yang tidak berdasar, seperti menumbuhkan gethoisme yang dengan mudah menimbulkan cakar-cakar antarpemeluk agama di muka bumi. Saat ini dan masa akan datang hsrud dirumuskan keberagamaan yang santun dengan semua tradisi agama-agama. Keberagamaan yang lebih responsif pada problem sosial dan keberagamaan yang lebih kritis akan keimanan sendiri, sebab keimanan yang kritis mampu membawa umatnya menuju keselamatan secara pribadi dan jamaah. Keberagamaan yang kritis merupakan keberagamaan yang reflektif dari seorang yang beriman kepada Tuhan, sehingga manusia tidak akan memaksakan pemahamannya pada orang lain yang dianggap berbeda pemahaman. Disinilah seharusnya Nahdlatul Ulama (NU) hadir dalam menawarkan kearifan universal profetik agama di masyarakat yang tengah memgalami kegalauan dahsyat di era global.

\section{Metode Penelitian}

Penelitian ini merupakan penelitian kepustakaan (library research). Menggunakan pendekatan perspektif historis, yakni suatu metode kajian dan sumber lain yang memuat informasi tentang masa lalu dan dilakukan secara sistematis. Dengan tujuan memahami masa lalu, dan berusaha memahami masa kini 
atas dasar peristiwa atau perkembangan di masa lampau. Serta dapat memperkaya pengetahuan tentang bagaimana dan mengapa suatu peristiwa masa lalu terjadi dan proses bagaimana masa lalu menjadi masa kini, pada akhirnya diharapkan dapat meningkatkan pemahaman tentang peristiwa terkini dan memperoleh dasar yang lebih rasional bagi membuat pilihan saat ini.. Pengumpulan data dibagi menjadi dua yaitu data primer dan sekunder. Sumber data diperoleh dari buku, jurnal, artikel, disertasi, skripsi hingga halaman website, dll yang berguna untuk membantu dalam penulisan penelitian ini. Setelah data terkumpul, selanjutnya data tersebut dianalisis dengan menggunakan teknik Miles dan Huberman yang terdiri dari reduksi data, penyajian data, atau analisis, kemudian tahap terakhir adalah penarikan kesimpulan.

\section{Hasil dan Pembahasan}

\subsection{NU dan Politik}

NU adalah organisasi berbasis Islam terbesar di Indonesia bahkan juga dunia. Tiada organisasi berbasis Islam yang diorganisir dengan struktur lembaga dan keanggotaan yang rapi semacama NU, setelah sebelumnya ada Muhamadiyah menjadi senior (didirikan lebih dahulu). NU memiliki basis pengikut berkisar 80-90 juta, hal ini sebagaimana yang disampaikan oleh KH. Mustofa Bisri (Gus Mus) dalam beberapa kesempatan ceramahnya diberbagai daerah. ${ }^{4}$ Nahdlatul Ulama sebagai

\footnotetext{
${ }^{4} \mathrm{KH}$. Ahmad Musthofa Bisri yang biasa di sapa Gus Mus, lahir di Rembang, Jawa Tengah 10 Agustus 1944. Alumnus dan penerima beasiswa
}

jam'iyyah diniyah adalah wadah bagi para ulama dan pengikutnya yang didirikan pada tanggal 16 Rajab 1344 H/31 Januari 1926 M. Dengan tujuan untuk memelihara, melestarikan, mengembangkan dan mengamalkan ajaran Islam yang menganut Ahlussunnah Wal Jama'ah dan taat. salah satu dari empat mazhab masing-masing Abu Hanifah An-Nu'man, Imam Malik bin Anas, Imam Muhammad bin Idris Asy-Syafi'i dan Imam Ahmad bin Hanbal, serta untuk menyatukan langkah para ulama dan pengikutnya dalam menjalankan aktivitas yang bertujuan untuk mewujudkan kemaslahatan masyarakat, kemajuan bangsa dan harkat martabat manusia. ${ }^{5}$

Tak heran, dengan jumlah pengikut yang begitu banyak setiap menjelang pemilu, NU ibarat madu di taman yang siap disedot kumbang. NU ibarat rumah besar yang menyimpan banyak madu. Kunjungan Capres dan Cawapres ini bukan sekedar silaturahmi, tetapi sekaligus menjadi "bargaining chip" politik, baik untuk jabatan menteri, direktur jenderal, inspektur jenderal, dan lain-lain. Apalagi warga NU dikenal ramah, terbuka,

dari Universitas Al-Azhar Cairo (Mesir) pada tahun 1964-1970) untuk studi Islam dan Bahasa Arab ini, juga pernah nyantri di berbagai pondok pesantren seperti: Pesantren Lirboyo Kediri di bawah asuhan KH. Marzuqi dan KH. Mahrus Ali, Al-Munawwar Krapyak Yogyakarta dibawah asuhan KH. Ali Ma'shum dan KH. Abdul Qadir. Lihat A. Mustofa Bisri, Tadarus (Antologi Puisi), 2003, h. 112; Mencari Bening Hati, 2009, h. 112

${ }^{5}$ Khittah dan Khidmah: Kumpulan Tulisan Majma' Buhuts An-Nahdiyyah, (Pati: Roudloh AlThohiriah, 2014), 42 
toleran, mudah pemaaf, dan mudah diarahkan oleh tokoh-tokoh lokal. ${ }^{6}$

Nahdlatul Ulama (NU) mempunyai peran penting dalam perjalanan hidup berbangsa dan bernegara. Dalam catatan sejarah bangsa Indonesia, NU pernah menjadi sebuah partai besar yang kagumi sekaligus disegani. Namun pada tahun 1926 bertempat di Pondok Pesantren Salafiyah Syafi'iyah Sukorejo Situbondo, Jawa Timur pada tanggal 13-16 Robi'ul Awwal $1404 \quad$ H/18-21 Desember 1983 M, akhirnya memilih keluar dari dunia percaturan politik praktis. Penjelasan mengenai khittah NU secara sederhana sebagai berikut: Pertama, Khittah Nahdlatul Ulama adalah landasan berfikir, bersikap, dan bertindak warga Nahdlatul Ulama yang harus tercermin dalam perilaku individu dan organisasi serta dalam setiap pengambilan keputusan. Kedua, Landasannya adalah ideologi Islam Ahlusunnah Wal Jam'ah yang diterapkan sesuai dengan kondisi masyarakat Indonesia, meliputi dasar-dasar agama dan perbuatan sosial. Ketiga, Khittah Nahdlatul Ulama juga disarikan dari esensi sejarah khidmahnya dari masa ke masa.

Nahdlatul Ulama memiliki prinsip pendirian keagamaan tawasuth dan I'tidal, yang berarti suatu sikap hidup yang menjunjung tinggi berlaku adil dan lurus dalam keharmonisan hidup bersama. Menjadi kelompok panutan dengan mengayomi dan mengemong serta membangun serta

\footnotetext{
${ }^{6}$ Ahmad Nurhasim dan Nur Kholik Ridwan, Demoralisasi Khittah NU dan Pembaharuan, (Yogyakarta: Pustaka Tokoh Bangsa, 2004), h. 11
}

menghindari segala bentuk sikap ekstrim. ${ }^{7}$ Selanjutnya adalah sikap Tasamuh, yakni suatu sikap menghargai perbedaan pola pemikiran dan tafsiran dalam bidang keagamaan, khususnya yang bentuknya cabang (baca: furu'), kebudayaan, hingga sosial-politik. Tawazun yaitu suatu sikap menyeimbangan pengabdian hidup kepada Allah Swt., sesama manusia (muamalah) dan alam sekitar. Dan terakhir adalah Amal Ma'ruf Nahi Munkar, mendorong berlaku untuk kebaikan dan kebajikan serta menepikan perilaku keburukan yang mendeskreditkan manusia sebagai makhluk Tuhan yang mempunyai hak sama. ${ }^{8}$

\subsection{Potensi Konflik dan Perpecahan}

Banyak kalangan menilai, Pilpres tahun 2019 berlangsung dengan sarat isu agama. Salah satu pendapat yang muncul diungkapkan oleh peneliti senior dari Lembaga Ilmu Pengetahuan Indonesia (LIPI) Ahmad Najib Burhani. Menurut dia, selama masa kampanye lalu, fanatisme dukungan terhadap calon presiden dan wakil presiden, baik nomor urut 01 maupun 02 , sudah pada tingkat seperti memperjuangkan agama (Islam), pertarungan muslim dengan nonmuslim, kelompok Islam dengan kelompok yang mengaku lebih Islami,

7 Ekstrim merupakan suatu bentuk pemahaman agama yang kaku, dogmatis dan menafikan akan keberadaan pemahaman keagamaan dan kemanusiaan yang lain. Gerakan ekstrimisme di Indonesia telah menjamur layaknya jamur di musim hujan, mereka dengan cepat menancapkan ideologinya, diantara sebab utamanya adalah fenomena instanisme style beragama.

${ }^{8}$ Kutipan ceramah KH. Said Aqil Siradj (Ketua Umum Nahdlatul Ulama) di media sosial youtube.com 
atau antara santri milenial dengan santri tradisional hingga akhirnya kerusuhan pecah pada tanggal 22 Mei 2019 yang lalu.

Pemilu 2019 mampu dikatakan sebagai sebagai pelanjut estafet sejarah dunia demokrasi di Indonesia, pada saat kita semua bermimpi mendambakan sebuah sistem politik yang terbuka, inklusif, toleran, dan tentu saja demokratis. Hanya saja terdapat persoalan yang saling berkelindan menyelimuti pemilu 2019 (pasca reformasi) yang menimbulkan bara api yang menyelimuti hampir seluruh penjuru negeri hingga saat ini. Mulai dari belum habisnya kelompok teror bersenjata di Papua yang setiap waktu dengan tanpa berkemmanusiaan membunuh warga sipil dan personil keamanan dari TNI dan Polri. Kerusuhan berbau agama-politik yang melibatkan para generasi muda di negeri ini. Kebakaran hutan yang seakan disengaja oleh orang-orang berkepentingan atas nama pembukaan lahan baru kelapa sawit. Hingga yang terbaru adalah gegap-gempita sidang para wakil rakyat yang menimbulkan polemik berkepanjangan.

Jauh-jauh hari, KH. Said Aqil Siradj (Ketum PBNU) pada Jum'at, 19 April 2019 memberikan konferensi pers di kantor PBNU, Jakarta. Disana juga hadir Lembaga Persaudaraan Ormas Islam (LPOI) yang menghimbau seluruh umat Muslim dan masyarakat agar bersabar menunggu hasil resmi pemilu 2019 dari KPU. ${ }^{9}$ KH. Said Aqil Siradj, berpesan seluruh pihak hendaknya mampu berbedar hati menerima hasil

${ }^{9}$ Lihat media online www. tempo.com edisi 19 April 2019 rekapitulasi suara dari Komisi Pemilihan Umum (KPU). Jangan sampai kepentingan kelompok mengalahkan kepentingan masyarakat dan negara. Beliau meminta masyarakat belajar pada negara-negara tetangga yang mengalami perpecahan dan kerusuhan yang terjadi di Afghanistan dan Timur Tengah.

Potensi perpecahan tersebut, ditegaskan kembali oleh Buya Syafi'i Ma'arif di dalam bukunya Krisis Arab dan Masa Depan Dunia Islam bahwa, ${ }^{10}$ dengan menganalogikan dengan model konflik yang terjadi di belahan Arab belakangan ini ternyata bukanlah konflik konflik keagamaan, tetapi lebih dari itu, ini adalah konflik politik antar elite-Arab dalam memperebutkan kekuasaan yang terang jauh dari petunjuk langit. Namun yang menjadi pertanyaan, mengapa ajaran suci persaudaraan yang terkandung di dalam Alquran tidak mampu mengendalikan nafsu politik elit Arab, sehingga menimbulkan perpecahan dan konflik di antara mereka? Mengapa pesan perdamaian tentang persaudaraan antar umat beriman seakan-akan lari di hadapan makhluk yang bernama "politik kekuasaan" itu?

Peristiwa Perang Unta menjadi cikal bakal terjadinya krisis politik di kalangan elite Arab Muslim saat itu. Peristiwa tersebut, menurut Buya, adalah perang saudara pertama setelah 24 tahun Rasul wafat. Dalam perang tersebut, tak tanggung-tanggung melibatkan para kader inti Nabi Muhammad Saw.

${ }^{10}$ Ahmad Syafi'i Ma'arif, Krisis Arab dan Masa Depan Dunia Islam, (Yogyakarta: Bentang Pustaka, 2018), h. 5 
berkonflik satu dengan lainnya. Diantaranya adalah kubu Ali bin Abi Thalib sepupu sekaligus menantu Nabi, yang di dalamnya ada sahabat Zubair bin Awwam dan Thalhah bin Ubaidillah. Peperangan kekuasaan pasca wafatnya Sahabat Utsman bin Affan. Ketidaksukaan Aisyah terhadap Ali adalah salah satu pemicunya. Sedangkan Thalhah dan Zubair adalah dua orang di antara sahabat yang dianggap sebagai calon kuat pengganti Utsman bin Affan pasca wafatnya pada $656 \mathrm{M}$. Peperangan ini dimenangkan oleh kubu Ali bin Abi Thalib, dan memuluskan jalan Ali menjadi khalifah (656-661 M).

Peperangan unta, perang lain yang lebih besar dan sangat menyesakkan adalah perang Shiffin yang mempertemukan yang mempertemukan antara Ali bin Abi Thalib dan Mu'awiyah bin Abu Sufyan. Perang ini menandai sebuah krisis politik elite Arab yang menciptakan akses perpecahan umat tanpa akhir hingga detik ini. karena setelah terjadinya perang ini muncul 3 puak besar, yang tidak hanya melahirkan pertikaian politik, tapi juga pertikaian teologis “perennial”, yakni Sunni, Syi'ah dan Khawarij yang keberadaannya dan interaksinya telah mengoyak persatuan dan ikatan persaudaraan dalam internal umat Islam. Kepentingan politik sesaat dengan dalil agama sekalipun bagi Buya, kepentingan politik dengan proposisi agama adalah pengkhianatan. Sunni, Syiah, dan Khawarij adalah buah perpecahan politik, lalu mengapa mereka diidolakan? Penyembahan berhala ini selama ratusan tahun telah menghancurkan persaudaraan sejati
Muslim, termasuk Muslim yang tidak ada hubungannya dengan budaya Arab yang memecah belah.

Fenomena perpecahan dan perkelahian antar sahabat dan kader sejati Nabi tidak lain adalah tingkah laku yang jelas tidak konsisten, kontradiktif, bahkan dalam bahasa Buya merupakan pengkhianatan terhadap pesan suci Alquran tentang persaudaraan. Ketika pertikaian antarsesama itu kita warisi sampai detik ini, baik atas dasar keangkuhan teologis, syahwat politik, egoisme tribal maupun sektarianisme, maka sesungguhnya kita tengah melanggengkan pengkhianatan terhadap al-Qur'an dan ajaran utama yang ada di dalamnya. Dan semua itu ternyata menjadi belenggu bagi masa depan Islam dan umatnya.

\subsection{Nahdlatul Ulama dan Moderasi Agama}

NU merupakan organisasi yang sudah menjadi mercusuar di Indonesia, sejak lahir 74 tahun lalu. NU dikenal sudah merasakan pahit-manisnya pergulatan politik di negeri ini, semenjak era sebelum kemerdekaan, orde lama, orde baru hingga zaman reformasi. Tentunya dalam sekian dekade perjalanannya, NU mampu diibaratkan seorang orang tua yang bijaksana dalam memimpin anak-anaknya menuju kemaslahatan di dunia hingga akhirat. Disamping sisi tentunya tidak bisa melepaskan sosok-sosok mulia yang memberikan dedikasi dan pengorbanannya dalam jatuh bangun perjuangan NU. Indonesia merupakan negara dengan kombinasi civil society yang dibangun berdasarkan keanekaragaman suku dan ras serta agama. Sehingga, dibalik anugerah luar 
biasa yang diberikan kepada bangsa Indonesia, ternyata juga menyimpan titik bara api yang setiap saat mampu tersulut dan membakar indahnya kemajemukan di negeri ini. Potensi pergesekan diantara masyarakat yang berlatarbelakang perbedaan cara pandang dan dukungan politik begitu terasa dirasakan, khususnya dalam penghelatan pemilihan presiden yang belum lama dilalui. Masyarakat Indonesia menjadi terkotak-kotak dalam sekat golongan politik, bahkan menjerumus ke dalam bentuk pendeskreditan humanisme dan agama dalam bingkai NKRI.

Nahdlatul Ulama sebagai kekuatan masyarakat sipil arus utama tentu mengkhawatirkan situasi sosial ke depan apabila tingkat emosional publik menjadi bara api yang dimanfaatkan pihak-pihak tertentu untuk menyulut terjadinya konflik komunal. Untuk hal itu, agar tidak terulang kembali, kita semestinya belajar dari bencana kekerasan sektarian di Maluku (1999-2002) yang meletus karena sentiment agama dan Kalimantan Tengah (2011) yang meledak gara-gara kebencian etnis.

Potensi perpecahan senantiasa terjadi bila setiap individu dan kelompok tidak berupaya saling berlapang dada. Apalagi, saat ini ada kecenderungan dari kelompok tertentu yang ingin memaksakan identitasnya muncul dan mendominasi ruang publik. Sebab itu, penting bagi Muhammadiyah untuk memainkan peran sebagai penerangan kepada publik dalam merajut kembali bilai-nilai keharmonisan yang telah terkoyak. Meskipun pekerjaan itu terbilang berat, karena konservatisme keagamaan yang terlanjut mengkristal, tidak berarti NU boleh memilih diam. Salah satu wujud memainkan peran sebagai penerangan kepada masyarakat adalah dengan menjadi organisasi Islam berwatak tengahan (Islam wasathiyah) diantara bentuknya dengan memoderasi keagamaan agar masyarakat tidak mudah terprovokasi.

Moderasi dalam pemikiran hukum Islam menciptakan fikih yang moderat, yang bila diterapkan pada ranah relasi antarumat beragama dapat membangun relasi yang harmonis antar pemeluk agama. Fiqh semacam itu sebenarnya bukan hal baru dalam tradisi hukum Islam. Kebutuhan fikih moderat tidak bisa dilepaskan dari kebutuhan umat Islam dan membangun kehidupan berbangsa dan bernegara. Tantangan Indonesia adalah problem intoleransi, kekerasan, dan konflik yang di antaranya menggunakan simbol dan legitimasi agama.

\subsection{Reorientasi Pemikiran Keagamaan}

Setelah berjalan setengah abad lebih memang usdah tiba saatnya bagi generasi sekarang untuk menelaah ulang serta menguji kembali tantangan, peluang dan hambatan yang dihadapi oleh Nahdlatul 'Ulama, khususnya yang berkaitan dengan wilayah pemikiran keagamaan. Hal ini perlu, karena jauh berbeda dengan saat keduanya baru berdiri tujuh puluh tahun lalu.Sebagai organisasi yang hidup, wawasan pemikiran keislaman dan keagamaan kedua organisasi ini pasti mengalami perubahan di sana-sini, lantaran tantangan, peluang dan hambatan yang dihapi sudah berubah bentuknya. 
Agaknya tidak sepenuhnya tepat untuk mengatakan bahwa tantangan dan peluang yang dihadapi oleh organisasi ini, terutama dalam hal wawawan pemikiran keagamaan adalah sama saja, atau tidak mengalami perubahan, sehingga tidak perlu dilakukan review, reorientasi, modifikasi, penajaman atau pengurangan pada bagian tertentu.

Dalam era globalisasi ilmu dan budaya, hampir semua sendi-sendi kehidupan umat manusia mengalami perubahan yang dahsyat. Institusi sosial-kemasyarakatan, kenegaraan dan keluarga, bahkan tidak terkecuali institusi keagamaan tidak luput dari pengaruh arus globalisasi. Akibatnya, idiom, kosa kata, pertanyaan mendasar, filsafat hidup, perhatian, pemikiran dan gagasan, pola perilaku, pengetahuan manusia tentang realitas alam semesta, baik mengenai dunia fisika, kosmologi pun berkembang pesat sesuai dengan laju perkembangannya. pertumbuhan dan perkembangan laboratorium ilmiah. baik di bidang astronomi, biologi, bioteknologi dan lain-lain. Perubahan tingkat perekonomian suatu bangsa juga ikut merubah cara pandang bangsa tersebut terhadap realitas dunia. Dalam masa itu, mustahil rasanya jika corak dan nuansa pemikiran keagamaan yang dihadapi oleh generasi sekarang jauh berbeda disbanding dengan yang dialami oleh generasi setengah abad yang lalu.

Jika puluhan masa yang sudah, program organisasi keagamaan terfokus pada pengenyahan kolonialisme-imperialisme, sekarang sosok kolonialisme sudah berubah bentuk penampilannya. Untuk tatanan global sekarang, masalah-masalah besar sosial kemasyarakatan mengambil bentuk seperti "arah pembangunan", transformasi sosialpolitik dan budaya, kualitas sumber daya manusia, pengangguran, keterampilan tenaga kerja, nasib kaum buruh dan pekerja kecil, pekerja wanita, pertanahan, hak asasi manusia, polusi dan lingkungan hidup dan persoalanpersoalan lain yang lebih bersifat emporisrealistis, yang semuanya itu menuntut sumbangan pemikiran dan uluran tangan organisasi keagamaan (baca: Nahdlatul 'Ulama). Jika paradigm keagamaan yang lama lebih banyak menyangkut persoalan fiqih, aqidah, tafsir, hadits yang seringkali terkait dengan ibadah mahdhah, agaknya pemikiran keagamaan tersebut oleh generasi sekarang dirasakan masih global dan dogmatis. Generasi sekarang menginginkan pemikiran keagamaan lebih luas cakupannya daripada yang sudah mentradisi dalam literature klasik.

Jika ujung tombak perjuangan organisasi keagamaan semata-mata hanya terfokus pada langkah-langkah kongkret, amal perbuatan atau dakwah bil hal yang terlepas dari keterkaitannya sama sekali dari dunia pemikiran, maka secara otomatis aspek-aspek pemikiran memang tidak dianggap terlalu penting untuk diperhatikan bahkan cenderung untuk dijauhi dan diacuhkan. Apakah dakwah bil hal memang tidak terkait sama sekali dengan rancangbangun epistimologi pemikiran yang mendasari pergumulan, pergulatan dan pergolakan pemikiran dalam kehidupan manusia dengan cara hanya mencukupkan diri pada praktik-praktik ibadah mahdhah, 
meminjam istilah Fazlur Rahman adalah merupakan tindakan intellectual suicide yang bermaksud bunuh diri intelektual. ${ }^{11}$

Mengingat pola pikir manusia era industrialisasi dan makin transparannya sekatsekat agama dan budaya, sudah tiba saatnya umat beragama mengembangkan dan memekarkan dua bentuk pendekatan dan pemahaman terhadap keberagamaan manusia, yaitu pendekatan yang bersifat imani (believer) dan sekaligus pendekatan historian atau scientific. ${ }^{12}$ Sementara itu, M. Arkoun menyebutkan kedua pendekatan ini dengan istilah pendekatan taqdlidiyyah-taifiyyah dan pendekatan tarikhiyyah-ilmiyyah. ${ }^{13}$ Pendekatan taqlidiyyah-taifiyyah lebih bersifat apriori, sarat dengan truthclaim sehingga bercorak eksklusif dan lebih menekan finalitas dan pemutlakan suatu ajaran agama, sedangkan pendekatan tarikhiyyah-ilmiyyah lebih bersifat apostteriori, empiric, open ended, dialogis dan toleran tanpa meninggalkan normativitas ajaran agama yang dipeluknya sendiri.

Untuk era globalisasi dan digitalisasi budaya seperti sekarang ini, pendekatan religius yang hanya sebatas dimensi keimanan (baca: spiritual) tanpa melibatkan dialog pemikiran yang historis, terbuka, egaliter dan demokratis, kemungkinan besar akan dilakukan. mungkin kecuali untuk membentuk

11 Fazlur Rahman, Islam and Modernity: Transformation of an Intelectual Tradition, (Chicago: The University of Chicago Press, Chicago, 1982), h. 158

${ }^{12}$ Ian G. Borbaur, Issues in Sciensce and Religion, (New York: Harper Torch-book, 1996), h. 129

${ }^{13}$ M. Arkoun, Al-Fikr al-Islamy: Naqd wa Ijtihad, Terjemahan Hashim Salih, (London: Dar as-Sarqi, 1990), h. 293-299 pola pikir eksklusif, yang hanya berlaku di lingkungan internal yang sangat terbatas. Pola berpikir yang bersifat partikularistik demikian akan mengalami kesulitan jika berhadapan dengan wilayah atau masyarakat di luar lingkungan sendiri. Pola pikir seperti itu kurang mampu menghargai kelompok lain di luar wilayah internalnya. Di sisi lain, pendekatan religius yang bersifat saintifikilmiah juga bukannya tanpa risiko. Pendekatan saintifik yang hanya memandang agama sebagai fenomena sosial kurang mampu mengapresiasi kedalaman dimensi apresiasi agama yang dimiliki oleh setiap umat beragama. Pendekatan ilmiah terhadap fenomena sosial yang tidak memperdulikan dimensi keagamaan (al-bu'du ad-diniy) memang akan kering dari nilai-nilai spiritualitas. $^{14}$

Dalam era kehidupan yang mengglobal seperti saat ini, gabungan antara kedua jenis pendekatan terhadap agama adalah sangat diperlukan. Model pendekatan seorang believer (baca: manusia beriman) hanya dapat mengantar kepada wawsan keagamaan seseorang yang terbatas pada lingkungannya sendiri. Kategori pemikiran dan pemecahan yang bersifat hitam-putih seperti dikotomi antara minna dan minhum, antara Muslim dan kafir, sejak awal mula sejarahnya memang tidak dapat dilepaskan dari konsepsi politik yang dibentuk oleh zamannya. Pendekatan politik yang sangat diwarnai interes kekuasaan seringkali kurang memperhatikan dimensi

\footnotetext{
${ }^{14}$ Ibid., h. 259-62. Perbandingan lihat pada A. Mukti Ali, Metode Memahami Agama Islam, (Jakarta: Bulan Bintang, 1991), h. 5-32
} 
ruhaniyah-spiritualitas keagamaan yang mendalam, yang teramat sulit untuk dikategorikan secara clear cut demikian. ${ }^{15}$

Kecurigaan terhadap kelompok di luar diri dan kelompok sendiri lebih diutamakan daripada kerjasama antara berbagai kelompok masyarakat yang saling berbeda.

Klaim kebenaran ajaran agama Islam perlu dibarengi dengan kemampuan mengartikulasikan pemikiran yang akurat dalam bidang bahasa, pola pikir dan historisitas. Peluang untuk beriman itu akan selalu saja ada, hanya saja apakah metode penyampaian keimanan itu masih sesuai dan "nyaman" didengar oleh kekuatan pasar atau tidak. Apakah bahasa yang digunakan menyejukkan, ramah, dalam arti diskusabel, terbuka, toleran, atau bersifat mencurigai, yakni lantaran truth claim terlalu keras dalam arti tertutup, dikotomis. Kesemuanya itu ditentukan oleh kaya atau miskinnya kepedulian para pemuka organisasi keagamaan (baca: Nahdlatul Ulama) terhadap perkembangan literature dan perkembangan pola berpikir masyarakat. Jika bahasa dan metode yang digunakan tidak enak untuk didengar oleh kelompok pendengar, maka keberimanan itu akan tetap ada, akan tetapi uraian dan penyampaiannya tidak hidup, tidak lincah, tidak menarik seperti yang diharapkan oleh telinga pendengar yang sudah terbiasa berubah cita rasa pendengaran dan pemikirannya akibat arus cepat globalisasi

15 Fazlur Rahman, Membuka Pintu Ijtihad, terjemahan Anas Mahyudin, (Bandung: Pustaka, 1984), h. 90. Bandingkan dengan W. Montgomery Watt, Islamic Philosophy and Theologi, (t.t: Edinburg at the University Press, 1962), h. 90 ilmu dan budaya. Jika proses ini berlangsung terus, lambat laun orang akan meninggalkan pasar tradisional dan pindah ke supermarket. ${ }^{16}$ Proses demikian tidak perlu disesali lantaran yang dirasa lebih menyejukkan hati sesuai dengan tingkat perkembangan dan tantangan historisitas kemanusiaan mereka.

Di sini barangkali, bahwa agama memang tidak semata-mata hanya terkait dengan praktik-praktik dan amalan-amalan (attuqus was-sya'air ad-diniyyah) yang tetap, tidak berubah-ubah seperti sediakala, tetapi juga menyangkut pemikiran-pemikiran yang selalu berubah-ubah sesuai irama historisitas kemanusiaan yang dilaluinya. Namun justru dalam wilayah yang terakhir, yakni dalam wilayah pemikiran inilah kebanyakan para tokoh dan pemuka agama selalu khawatir dan curiga menghadapinya. Rasa khawatir itu terlebih-lebih lagi dirasakan oleh para fungsionaris organisasi keagamaan (baca: Nahdlatul Ulama) lantaran mereka selalu dibayangi-bayangi dan terbebani tanggung jawab bimbingan yang "pasti" dan "final" kepada umat. Pada akhirnya, dirasanya payah menghadapi arus realitas globalisasi ilmu dan budaya berikut dampak yang dibawanya jika pemikiran keislaman tidak juga mengembangkan segi-segi pemikiran

16 Golongan tradisional pada umumnya dimaknai oleh para cendikiawan merupakan corak daripada Nahdlatul Ulama yang pada realitasnya berada di wilayah yang erat dengan kultur pendesaan. Sementara supermarket (baca: modern) diidentikkan dengan Muhammadiyah, salafi (wahabi), FPI, HTI dan lainnya. wilayah penyebaran kegiatan dakwahnya berpusat di sentral perkotaan. 
keagamaan yang lebih substansial dan fundamental.

\subsection{Reorientasi Pendekatan Konflik}

Konflik-konflik berdarah yang terjadi hampir dalam seluruh rentangan sejarah agama-agama di dunia tanpa terkecuali, Indonesia. pada akhirnya menimbulkan pertanyaan mengenai kemampuan umat beragama untuk membangun suatu peradaban yang kuat nan santun bagi suatu tatanan masyarakat majemuk seperti Indonesia. Pesimisme didasarkan pada gejala-gejala menguatnya pandangan tempurung pada banyak kelompok agama yang menganggap bahwa agama yang mereka anut adalah sutusatunya agama yang benar dan karenanya orang lain harus mengakui kebenarannya dan boleh dijadikan objek dakwah. Jika Anda menolak menanggapi secara positif dakwah itu, orang-orang seperti itu hendaknya tidak diberi hak yang sama dengan hak-hak orang lain dari kelompok itu. Orang dengan pendapat ini merasa cukup mampu untuk bekerja dan hidup dengan kelompoknya sendiri, tanpa harus bekerja sama dan berbagi dengan orang lain di luarnya.

Terdapat kekacauan dalam melihat hakikat agama, antara lain: pertama, yang bersifat keyakinan personal. Kedua, yang bersifat umum dalam aliran-aliran yang berbeda dari agama yang sama. Ketiga, bersifat universal dalam setiap agama. Apa yang dianggap benar dalam tataran pribadi, walaupun tidak jarang dipakai untuk mengukur kebenaran umum, sebenarnya belum tentu benar, karena kelemahan yang melekat pada inividu, seperti pandangan yang hanya terbatas pada satu-dua aspek dari kenyataan, tidak komprehensif. Untuk mencapai pandangan yang komprehensif, perlu pandangan orang lain dari aspek dan sudut pandang yang lain pula. Sebaliknya, ada hal-hal yang sebenarnya sama dimiliki oleh setiap agama, namun dianggap oleh pemeluk agama tertentu hanya pada agamanya. Mislanya, ajaran mengenai penghargaan kepada martabat manusia, kejujuran, keadilan, keharmonisan, tenggang rasa dan pengendalian diri. Anggapan seperti ini timbul antara lain karena fanatisme buta kepada ajaran atau tradisi agama sendiri dan ketidaktahuan akan tradisi agama lain. Demikian pula mengenai hal-hal yang khas dalam suatu agama dan dipegangi oleh setiap aliran yang ada di dalamnya, pengikut suatu aliran tidak jarang menganggap bahwa hal itu hanya ada dalam alirannya sendiri. ${ }^{17}$

Ignas Kleden mengutarakan bahwa, pada hakikatnya agama menjunjung tinggi penyelamatan dan keselamatan manusia, seharusnya para meluk agama bahu-membahu untuk menghadapi persoalan bersama ini, yakni menjaga umat manusia dan lingkungannya dari kerusakan dan pengrusakan. ${ }^{18}$ Emosi sering kali menguasai manusia, tidak kecuali para pemeluk agama. Di antara ajaran spiritualitas agama, yang mungkin dikatakan dalam setiap agama adalah penguasaan emosi. Namun anehnya, orang-

${ }^{17}$ Lihat Q.S. Surat al-Nahl ayat 93; Q.S. Surat al-Syura: 8;Q.S. al-Maidah: 48

${ }^{18}$ Ignas Kleden, Kebangkitan Agama dalam Tiga Dimensi, document Kompas, 03 April 1995, h. $4-5$ 
orang yang beragama seringkali mudah dikuasai emosi ketika merasa sedang melakukan tindakan untuk mempertahankan kesucian agama. Mungkin ini berasal dari anggapan bahwa hanya agama itu sendiri yang benar, tetapi bisa juga berasal dari egoisme, yang dalam hal ini secara tidak sadar direduksi menjadi tindakan religius.

Mengenai konflik, dapat dibangun teologi bahwa konflik merupakan aktivitas merugikan spiritualitas manusia, yang ditekankan dalam beragama. Konflik yang dilanjutkan dengan penggunaan kekerasan akan menyuburkan dominasi an-nafsu amarah. Tindakan yang berlabel agama, ketika didorong oleh nafsu amarah, menjadi tidak mempunyai nilai keagamaan, karena pada hakikatnya merupakan pelampiasan nafsu amarah. $^{19}$ Pelaku-pelaku dalam konflik masyarakat kadang-kadang tidak jelas sosoknya. Banyak dari kerusuhan bersifat massal dan tidak dapat ditimpakan tanggung jawabnya kepada individu. ${ }^{20}$

\subsection{Reorientasi Wawasan Ideologi}

Umat Islam tidak dapat mengetahui dengan pasti tentang masa depan Islam. Bagi umat Islam abad-abad yang akan datang sudah

19 Ali Ridho dan Thibburruhany, Prinsip Toleransi Beragama Sebagai Pondasi Membangun Peradaban Islam di Era Modern, El-Afkar Vol. 8, Nomor 1, Januari-Juni 2019, h. 1

$$
20
$$

Lihat

https://m.cnnindonesia.com/internasional/20180306 182807-113-280921/bentrok-muslim-buddha-srilanka-nyatakan-status-darurat; https://www.benarnews.org/indonesian/berita/pemb akaran_masjid_papua memicu_konflik07202015182625.html;

https://www.dw.com/id/aceh-membara-disulutkonflik-agama/a-18780213 barang tentu diharapkan akan dapat diisi dengan berbagai macam kegiatan, sebagai mazhar kehadiran Islam, yang berguna bukan hanya bagi umat Islam tetapi juga bagi seantero umat manusia. Tetapi apa kegiatankegiatan Islam itu secara terinci sudah barang tentu orang tidak dapat mengetahuinya dengan pasti. Tetapi suatu hal yang terang bahwa dunia Islam dewas ini berada dalam rangka proses yang panjang dan proses yang belum lengkap.

Bagi seorang Muslim, masyarakat dan sejarah mempunyai arti khusus dilihat dari segi agama. Sudah barang tentu di mata orang Islam al-Qur'an itu suci. Tetapi orang jangan salah mengerti dan terlalu jauh menyatakan bahwa masyarakat Islam dan sejarahnya mempunyai kualitas yang suci. Inilah suatu masyarakat yang dengan jelas berusaha untuk hidup sesuai dengan kehendak Tuhan. Sejak dari adanya, menjadi Muslim juga berarti mengikuti masyarakat Islam dan mengambil bagian dalam usaha mencari keridhaan Tuhan di bumi.

Masyarakat Islam diikat menjadi satu bukan hanya karena loyalitas dan tradisi yang sama, dan bukan karena adanya sistem nilai dan kepercayaan yang baik. Masyarakat Islam juga bukan hanya merupakan produk cita yang baik. Masyarakat Islam berdenyut bersamasama dengan vitalitasnya keyakinan yang mendalam, yaitu keyakinan agama yang hangat dan berarti bagi tiap-tiap anggotanya. Dapat dikatakan bahwa masyarakat Islam merupakan pelahiran cita Islam. Sebagai sistem agama atau ideology bisa dilahirkan 
dalam bentuk intelektual dari keyakinan pribadi, demikian pula tatanan sosial dan aktivitasnya merupakan tempat kelahiran dalam wujud praktis dari keyakinan pribadi seorang muslim. Keanggotaan dalam masyarakat bukanlah sesuatu yang lain atau tambahan atau bahkan konsekuensi dari Islam, tetapi merupakan aspek dari Islam itu sendiri.

Gerakan Islam, tak jarang menggunakan kekerasan menjadi fenomena yang menonjol menyeruak di media nasional dan internasional. Kemunculan Islamic State of Iraq and Syria (ISIS) dan konflik membara dunia Islam di Timur Tengah cukuplah dikatakan sebagai puncak dari serentetan drama kekerasan berbau darah yang memakan korban orang-orang yang tak tahu apa yang sesungguhnya dipikirkan oleh para pelakunya. $^{21}$

Di negara-negara yang penduduknya beragama Islam mayoritas dan minoritas, ledakan kekerasan seakan tidak ada habisnya. Di Indonesia, serangan bom berulang kali menghantam daerah dari Jakarta hingga Surabaya, dan mengejutkan mayoritas Muslim di sini, sambil menahan rasa malu mereka bertanya-tanya apa yang sebenarnya dipikirkan para pelakunya. Jihadkah? Atau aksi terror? Kalau jihad, apa yang diperjuangkan dan dalil (h) apa yang membenarkan tindakan itu? Jika terror, siapa atau kelompok apa yang menjadi sasaran sehingga sasaran tersebut dicabut dan kemudian mengabulkan tuntutannya? Dan apa tuntutannya? Mengubah negara ini menjadi

\footnotetext{
${ }^{21}$ Lihat https:www.britanican.com; https:www.un.org/press/en/2019/sc13931.doc.htm, diakses pada 06 Oktober 2019
}

negara Islam yang mereka impikan? Mengusir segala sesuatu yang berbau Amerika, atau Barat sehingga lenyap dari bumi.

Sementara jabawan atas pertanyaan belum diperoleh, publik disuguhi drama lain berupa penangkapan, pemenjaraan, bahkan eksekusi hukuman mati atas orang-orang yang dianggap menjadi actor kerusuhan. Tetapi gerakan Islam tak kunjung padam. Sebuah organisasi baru dideklarasikan, dan demonstrasi dengan mengerahkan massa ke jalan-jalan ibu kota dan di kota-kota kecil terus berlanjut.. Aksi sweeping terhadap tempattempat maksiat, permusuhan dengan kelompok agama lain, terasa menu berita sehari-hari. Dengan suara yang keras, mereka berhasil menggoda media massa, khusunya media sosial (baca: youtube, instagram, facebook hingga twitter).

Penjelasan mengenai pertanyaanpertanyaan itu selama ini hanya dapat diperoleh dari Kepolisian. Memang tidak sepele, namun penjelasan dari pendekatan keamanan tersebut tentunya hanya menonjolkan sisi kriminalitasnya, dan sisi pergerakan yang lebih detail tidak mudah didapat. Pendekatan lain yang kerap menghiasi argumentasi dalam menjelaskan fenomena yang kerap muncul dalam debat televisi ini adalah "teori konspirasi", yang cenderung menempatkan fenomena ini sebagai permainan elit politik untuk mempertahankan kekuasaannya.. Seolah-olah gerakan semacam ini adalah perintah untuk melaksanakan episode "goro-goro" yang dirancang oleh dalang. Begitu pula dengan gencarnya 
kampanye "anti terorisme", fenomena ini dengan mudah dapat dibawa ke penjelasan hitam-putih, dengan mengabaikan kemungkinan dinamika yang muncul dalam gerakan Islam.

Rekomendasi yang sering muncul pun tak jauh dari analisis dari pendekatanpendekatan dangkal. Saat ini, terdapat kebutuhan yang semakin meningkat akan program audit senjata bagi mantan kombatan dalam konflik bersenjata, reintegrasi mantan kombatan ke dalam masyarakat normal, hingga program deradikalisasi, khususnya dengan pendekatan kesejahteraan (penyediaan lapangan kerja, bantuan ekonomi, dll). ${ }^{22}$ Nampak bahwa penjelasan fenomena gerakan Islam masih didominasi oleh anggapan bahwa gerakan Islam merupakan penyimpangan dari arus utama Islam, yang muncul karena didorong oleh rasa frustasi atas ketimpangan dan kemiskinan, sehingga mereka terjerumus ke dalam non tindakan -rasional, mudah terprovokasi dan dikuasai oleh kepentingan. di luar dirinya.

${ }^{22}$ Menurut K.H. Hasyim Muzadi, biasanya radikalisasi tumbuh berkaitan dengan ketidakadilan ekonomi, politik, lemahnya penegakan hukum dan seterusnya. Jadi, jangan dibayangkan ketika teroris sudah ditangkap, lalu radikalisme hilang. Sepanjang keadilan dan kemakmuran belum terwujud, radikalisasi akan selalu muncul di masyarakat. Keadilan itu menyangkut banyak aspek, baik aspek hukum, politik, pendidikan, sosial, hak asasi, maupun budaya. Hukum itu berbeda dengan keadilan. Hukum adalah aspek tertentu, sedangkan keadilan adalah akhlak dari hukum. Lihat Nurul Faiqah dan Toni Pransiska, Radikalisme Islam VS Moderasi Islam: Upaya Membangun Wajah Islam Indonesia Yang Damai, (Al-Fikra: Jurnal Ilmiah Keislaman, Vol. 17, No. 1, Januari-Juni, 2018), h.38 $\begin{array}{cccc}\text { Mayoritas studi aktivisme } & \text { Islam } \\ \text { menekankan keluhan mendasar yang }\end{array}$ mendorong tindakan kolektif, termasuk, misalnya, stagnasi mobilitas sosial, pengabnya kebebasan politik, keputusasaan ekonomi, rasa kerentanan budaya dan penghinaan. Penderitaan, seperti yang dikatakan Tedd Gurr, adalah sarang pemberontakan. Keberhasilan mobilisasi ditentukan oleh seberapa banyak sumber daya yang tersedia, serta jenis sumber daya dan struktur mobilisasi yang digunakan. ${ }^{23}$

Fenomena diatas jika dimasukkan dalam segi religiusitas, sebagaimana yang diungkapkan oleh Hosen Nasr di era tatanan dunia global, manusia kehilangan pengetahuan langsung tentang diri dan keakuannya, yang disebabkan oleh ketergantungan pada pengetahuan eksternal (baca: pemikiran apriori atu klaim kebenaran mutlak) yang tidak langusng berhubungan dengan dirinya, serta tidak mengandung kesadaran yang menghubungkan manusia pada Ilahi. ${ }^{24}$

Kondisi yang dialami masyarakat dunia Barat tersebut, rupanya tidak jauh berbeda dengan apa yang terjadi di dunia Islam. Pada masa kontemporer ini mereka terombang-ambing oleh 3 kekuatan di satu

23 Istilah mobilisasi massa paling banyak muncul saat akan berlangsungnya penetapan dan sekaligus pelantikan presiden terpilih RI tahun 2019. Sebagaimana diberitakan oleh www.tempo.com/tag/mobilisasi- massa. mobilisasi massa juga dapat dipotret dari pergerakan demonstrasi terhadap kasus dugaan penistaan agama di Jakarta hingga di Hongkong baru-baru ini.

24 M. Subhi, Desakralisasi dan Alenasi Manusia Dalam Peradaban Modern Persepektif Sayyed Hossein Nasr, Jurnal Universitas Paramidana, 2014, h. 1121 
pihak kekuatan tradisi Islam dan di pihak lain kekuatan sekularisasi, radikalisasi dan modernisasi. Secara universal, Nasr berpandangan bahwa kesadaran manusia harus dikembangkan dengan baik dengan senantiasa menciptakan keselarasan antara makhluk hidup dan membangun habitat hingga ekosistem yang seimbang antar makhluk lain. Disini Nasr mengimplikasikan terciptanya kesadaran spiritual yang tinggi sampai pada tataran memelihara alam dan isinya. ${ }^{25}$

Maka, Nahdlatul Ulama perlu menawarkan jalan melalui Islam tradisionalitas yaitu Tasawwuf. Jika nilai-nilai tersebut terjawantahkan dalam kehidupan umat muslim dalam sehari-hari, maka fakultas kehidupan yang lebih harmonis mampu diciptakan. Meminjam konsep Hossein Nasr, perlu adanya sufisme dalam tatanan masyarakat modern ini dengan tujuan, pertama, tutut serta terlibat dalam berbagai peran untuk menyelamatkan kemanusiaan dari kondisi kebingungan akibat hilangnya nilainilai spiritual. Kedua, memperkenalkan literature atau pemahaman tentang aspek eksoteris (ruhani Islam), baik terhadap masyarakat Islam yang mulai melupakannya maupun non-Islam, khususnya terhadap masyarakat dunia Barat. Pemahaman tentang literature tersebut supaya manusia modern memiliki pedoman upaya hidupnya lebih terarah serta menjadi harmonis dalam menjalankan kehidupannya. Ketiga, untuk menegaskan kembali bahwa sesungguhnya aspek esoterik Islam yaitu tasawuf merupakan

25 Sayyed Hossein Nasr, In Search of the Sacred, (New York: Sunny Press, 1989), h. 114 jantung dari ajaran Islam, sehingga jika wilayah ini kering dan berdenyut maka aspek Islam yang lain akan mengering. Setiap manusia sudah mulai dengan kehidupannya yang materialistik, sufi disini mengingatkan kembali serta menegaskan kembali bahwa jasad haruslah disertai dengan ruh yang menopangnya.

Gagasan Nasr di atas bermaksud untuk menghidupkan kembali ilmu-ilmu tradisional dan kosmologis di tengah dunia modern yang akan mampu berperan dalam membangkitkan kesadaran akan kesatuan ilmu dan ilmu spiritual. Dengan kembali kepada spiritualitas di tengah arogansi dan kebingungan modernitas di dunia yang mengglobal adalah mengembalikan rasa kehadiran Dzat Suci di tengah akhlak manusia yang sebenarnya dipercayakan oleh-Nya kepada setiap jiwa manusia, spiritualitas adalah sebuah Ide tak terbatas yang melekat dalam totalitas kemanusiaan manusia, menyangkalnya berarti menyangkal diri sebagai manusia. Oleh karena itu, tawassuf adalah cara terbaik untuk membawa transendensi, karena tawassuf merupakan keharusan ketika kesengsaraan dialami manusia. $^{26}$

\section{Simpulan}

Nahdlatul 'Ulama menjadi potret sekaligus representasi bagi dunia internasional maupun nasional. Bahwasannya Islam mampu menjadi pemimpin peradaban dan

26 A. Nurchlosih, Peran Tasawwuf dalam Merekonstruksi Krisis Spiritualitas Manusia Modern, Jurnal Sosio-Religia, 2012. 
berkemajuan manakala mampu mengoptimalkan, pertama, pemikiran keagamaan, dengan menggali khazanahkhazanah pengetahuan masa lalu dan terbuka. Dengan mengesampingkan egoisme kepentingan-kepentingan pragmatis dan golongan. Kedua, menjadi penyiram air untuk api konflik yang terjadi hampir setiap saat, serta memberikan solusi yang sifatnya berkepanjangan melalui pendekatan model Islam yang moderat. Ketiga, kembali mempelajari jantung Islam dan memakainya dalam baju perilaku kepada Tuhan dan kemanusiaan yaitu Tasawwuf (baca: spiritual ruhani), yang di zaman global saat ini, telah perlahan ditanggalkan dalam menjalani ritus kehidupan.

\section{Daftar Pustaka}

Ali, A. Mukti. 1991. Metode Memahami Agama Islam. Jakarta: Bulan Bintang.

Arkoun, M. 1990. Al-Fikr al-Islamy: Naqd wa Ijtihad. Terjemahan Hashim Salih. London: Dar as-Sarqi.

Bisri, A. Musthofa. 2014. Khittah dan Khidmah: Kumpulan Tulisan Majma' Buhuts An-Nahdiyyah. Pati: Roudloh AlThohiriah.

\section{Hati.}

2009. Mencari Bening

2003. Tadarus (Antologi

Puisi).

Faiqah, Nurul dan Pransiska, Toni. 2018. Radikalisme Islam VS Moderasi Islam: Upaya Membangun Wajah Islam Indonesia Yang Damai. Al-Fikra: Jurnal Ilmiah Keislaman 17 (1) Januari-Juni.
G. Borbaur, Ian. 1996. Issues in Sciensce and Religion. New York: Harper Torch-book.

Hossein Nasr, Sayyed. 1989. In Search of the Sacred. New York: Sunny Press.

Nurchlosih, A. 2012. Peran Tasawwuf dalam Merekonstruksi Krisis Spiritualitas Manusia Modern. Jurnal Sosio-Religia.

Nurhasim, Ahmad dan Ridwan, N.K. 2004. Demoralisasi Khittah NU dan Pembaharuan. Yogyakarta: Pustaka Tokoh Bangsa.

Rahman, Fazlur. 1982. Islam and Modernity: Transformation of an Intelectual Tradition. Chicago: The University of Chicago Press, Chicago.

1984. Membuka Pintu Ijtihad, terjemahan Anas Mahyudin. Bandung: Pustaka.

Ridho, Ali. 2019. Memahamai Makna Jihad Dalam Serial Film Kartun Cisform: Jihad FiSabilillah (Analisis Wacana Teun A. Van Dijk). Jurnal Dakwah dan Komunikasi IAIN Curup. 4 (1).

Ridho, Ali dan Thibburruhany. 2019. Prinsip Toleransi Beragama Sebagai Pondasi Membangun Peradaban Islam di Era Modern. Jurnal El-Afkar 8 (1) JanuariJuni

Subhi, M. 2014. Desakralisasi dan Alenasi Manusia Dalam Peradaban Modern Persepektif Sayyed Hossein Nasr. Jurnal Universitas Paramidana.

Syafi'i Ma'arif, Ahmad. 2018. Krisis Arab dan Masa Depan Dunia Islam. Yogyakarta: Bentang Pustaka.

Watt, W. Montgomery. 1962. Islamic Philosophy and Theologi. t.t: Edinburg at the University Press. 